\author{
Shan X., \\ PhD Student at the Department of History of Law and State \\ of the Faculty of Law \\ of Taras Shevchenko National University of Kyiv \\ ORCID: 0000-0003-2282-9808
}

\title{
PRINCIPLES OF CRIMINAL LAW IN THE SOVIET DOCTRINE AND THE LEGISLATION OF THE SECOND HALF OF THE 20TH CENTURY
}

\section{ПРИНЦИПИ КРИМІНАЛЬНОГО ПРАВА В РАДЯНСЬКІЙ ДОКТРИНІ ТА ЗАКОНОДАВСТВІ ДРУГОЇ ПОЛОВИНИ ХХ СТ.}

The article deals with the evolution of the concepts of "the principles of law" and "the principles of criminal law" in Soviet legal doctrine and legislation. It provides the basic definitions for the above terms elaborated by Soviet theorists in the second half of the twentieth century. It states that the whole variety of definitions for the term "the principles of law," mentioned in the legal literature of Ukraine, narrows down to two of them, in fact. In the first case, the principles of law are defined as the basic ideas, originating provisions, and in the second - normative provisions of law, which determine the general focus, the main peculiarities and the most essential features of legal regulation. The author also cites the definitions of certain concepts of "the principles of law" provided by Ukrainian scholars.

The article outlines the specific principles of criminal law. It supports the opinion of Soviet researchers on the existence of two groups of basic principles of Soviet criminal law. The first group includes those inherent in all branches of Soviet law, including criminal law, which are recognized as general principles of law, and the second group encompasses exclusively those inherent in the branches of criminal law. The paper defines the level of implementation of the principles of Soviet law in the legislation of the USSR and the Ukrainian SSR. It notes that the Soviet legal theory had made attempts to provide the definition for "the special principles of criminal law" and to determine their scope and concept. The article concludes that a number of principles of criminal law existing at the level of theoretical and criminal doctrine had never found their textual reflection in the Soviet criminal legislation.

Key words: principles of law, special principles of law, doctrine, legislation, crimes, criminal law.

У статті йдеться про еволюцію понять «принципи права» та «принципи кримінального права» в радянській правовій доктрині й законодавстві. Наведені основні визначення вказаного терміна, здійснені радянськими вченими в другій половині XX ст. Зазначено, що за всього розмаїття наукових визначень терміна «принципи права» наявні в юридичній літературі України підходи зводяться фактично до двох. У першому випадку принципи права визнаються основоположними ідеями, вихідними засадами, а в другому - нормативними засадами права, що визначають загальну спрямованість, основні особливості й найсуттєвіші риси правового регулювання. Наведено авторські визначення окремих понять «принципи права», що здійснені українськими авторами.

Перелічено спеціальні принципи кримінального права. Підтримана думка радянських дослідників щодо існування двох груп основних принципів радянського кримінального права. До першої групи належать ті, що притаманні всім галузям радянського права, у тому числі й кримінальному, які визнають загальноправовими, а до другої - виключно ті, що притаманні галузі кримінального права.

Наведені визначення та риси, притаманні принципам радянського кримінального права, що більшістю авторів уважаються водночас й ознаками, характерними саме для принципів кримінального права. Відзначено, що більшість дослідників радянської доби наводять перелік ознак, які вони зараховують до галузевих, уникаючи при цьому загального визначення терміна, що ними досліджувався. Зроблено висновок, що така невизначеність у ключових поняттях не дає можливості зрозуміти, що становлять спеціальні принципи кримінального права й у чому їх сутність.

Перелічені й охарактеризовані спеціальні принципи радянського кримінального права, які визнавалися дослідниками як такі, що притаманні соціалістичній системі права, характерній для Радянського Союзу загалом і Радянської України зокрема. Серед них радянські теоретики кримінального права визначали такі: принцип відповідальності за вину, принцип персональної кримінальної відповідальності, принцип відповідності кримінальної відповідальності небезпечності злочину і злочинця, індивідуалізація відповідальності за вчинений злочин, принцип притягнення до кримінальної відповідальності лише у випадку, коли виправлення й перевиховання винного не можуть бути забезпечені іншим шляхом.

3'ясовано рівень закріплення принципів радянського права в загальносоюзному та законодавстві УРСР. Розкрито зміст принципу відповідальності за вину, сформульований у ст. 3 Основ кримінального 
законодавства СРСР і союзних республік від 25 грудня 1958 р., що знайшов повне відтворення в ідентичній статті Кримінального кодексу УРСР від 28 грудня 1960 р. Він полягав у тому, що кримінальній відповідальності й покаранню підлягає лише особа, винна в учиненні злочину, тобто така, що умисно або з необережності вчинила передбачене кримінальним законом суспільно небезпечне діяння.

У заключній частині статті відзначено, що в науково-правовій літературі здійснені спроби визначення дефініції «спеціальні принципи кримінального права», наміри встановити їх коло та визначити зміст. Зроблено висновок, що низка принципів кримінального права існували на рівні теоретико- та кримінально-правової доктрини, не знаходячи свого відображення в текстах радянського кримінального законодавства.

Ключові слова: принциипи права, спеціальні принцчипи права, доктрина, законодавство, злочини, кримінальне право.

Introduction. The principles or foundations of law have been intensively elaborated in the scientific environment, both theoretical and sectoral, though no unified view has been reached yet.

In general, the principles of law are nothing but the basic ideas, originating provisions, guiding principles of its creation, development andfunctioning. Theyare reflected in the norms oflaw, permeate the entire legal existence of the people, the legal system of the state, and characterize not only the essence but also the scope of law. They demonstrate not only the internal structure of law, its static state, but also the process of enforcement, that is, its dynamics. It is the principles of law that have a great impact on the process of making laws, codes and other normative acts, as well as on their adoption, publication, and, ultimately, on the establishment of guarantees for law compliance. That is why the goal of this article is to investigate the transformation of "the principles of Soviet law" in the Soviet legal doctrine and legislation.

Statement of basic materials. The principles of law are objectively determined by the social, economic and spiritual interrelations, which developed in a particular country and depend on the nature of the state, its political regime as well as the basic foundations of both the society and the state.

"On the one hand," as the Ukrainian scientist O. Hryshchuk reasonably states "the principles of law reflect the spiritual, historical, social, political, cultural and other features of society by translating and modifying them in a generalized form, and on the other hand, the principles of law facilitate implementation of universally recognized social values, further their enforcement and application in legal practice" $[1, p .16]$. The social values are "objectified" through the real acts of people - legal persons, which considered to be both the makers and bearers, implementers of the principles of law [2, p. 145].

In its most general form, contemporary Ukrainian legal theorists suggest the following definitions for "the principles of law":

- P. Rabinovych sees them as the guiding principles (ideas) stemming from the objective laws of existence and development of a human and society, which determine the essence and areas of legal regulation [3, p. 105];
- O. Skakun considers them as the generally accepted norms (ideas) of the highest authority, which serve as the basic principles for regulation of social relations, and spur the member of society to the reach social compromise and establish the order [4, p. 242];

- S. Pohrebniak thinks that the principles of law are a system of the most general and stable imperative requirements enshrined in law. They are a concentrated implementation of the most essential features and values inherent in a law system and determine its nature and directions of further development [5, p. 24];

- Academician of the National Academy of Science of Ukraine O. Zaichuk holds a firm view that the principles of law are the originating, fundamental ideas, provisions, attitudes that form the moral and organizational ground for the creation, development and functioning of law [6, p. 23];

- L. Luts defines the principles of law as the basic normative grounds of positive law, which determine the nature and focus of legal regulation [7, p. 163];

- A. Kolodiy sees the principles of law as the originating ideas of society, which reflect the most crucial regularities, foundations of a particular state and its law system; are homogeneous to the society's identity and form its basic features; are distinct in universality, higher imperativeness and general importance; meet the objective necessity of building and strengthening a certain social order. Further, the scholar notes that the principles of law are permanently developed and evolved depending on the historical environment in which a society and the state exist, they adopt to the era, people, their needs, lifestyle and social relations [8, p. 43];

- M. Koziubra defines the principles of law as the most general and steady requirements which embody the social values, allow to implement them in the creation and application of law by defining its nature and focus for further development [9, p. 70].

As we can see, the full diversity of scientific definitions for the term "the principles of law" in the legal literature of Ukraine, in fact, comes down to two approaches. In the former case, the principles of law are recognized as basic ideas, originating (guiding) provisions, and in the latter case - they are the normative principles of law, which determine the general focus, the main 
peculiarities and the most essential features of legal regulation [10, p. 19].

Therefore, let us discuss the principles of criminal law of Soviet Ukraine, their transformation and place in the contemporary legal system of the independent Ukraine. However, it should be noted that the Soviet Union had no dividing line between the principles of criminal law in individual republics. All of them used the term "the principles of Soviet criminal law," which were the same in the law systems of all former USSR republics. The Soviet researcher, M. Yakub rightly believed that though the Soviet legislation established the principles of law, which were legally binding for all the Union republics, the key ideas and principles of criminal law had no binding effect on them, in fact [11, c. 60-61].

We shall note that it is difficult to find the definitions, attributes and features of the principles of criminal law in publications of Soviet Ukraine lawyers. They placed no specific scientific interest to the researchers.

It is the scholars from academic and educational institutions of the USSR's capital, Moscow, who worked in this area of scientific knowledge. M. Zagorodnikov, Head of the Department of Criminal Law, Higher School of the Ministry of Internal Affairs of the USSR, was one of the first who showed the correlation between the essential, fundamental ideas of the principles of criminal law, and the principles of law of other legal branches. He outlined the general principles, on one hand, and the specific principles of criminal law, on the other. The researcher believes that the first ones include the principles of socialist democracy, legitimacy, humanism and internationalism, whereas the second - comprehensive security of political, economic and national interests of the workers, fault-based and individual responsibility, involvement of people in the implementation and application of criminal law, crime prevention, concurrence of negative criminal assessment and moral assessment of actions been recognized as crimes [12, p. 71-74].

It was $\mathrm{H}$. Wittenberg who put an increased focus on the principles of criminal law immediately after the adoption of the criminal code of the USSR and the RSFSR (Russian Soviet Federative Socialist Republic), though not always well-grounded, in our opinion. He was one of the first in the Soviet theory of criminal law who defined the principles of criminal law. The scholar viewed them as those inherent only in criminal law as a separate branch of law $[13$, p. 88]. We consider that the cited statement has nothing to do with the definition, since it emphasizes only the affiliation of certain principles to the criminal law, but does not offer the essential features of the principles, which shall make them distinguishable. It also has no distinctive elements to differentiate between the principles of criminal law and those of other branches of law.

As $H$. Wittenberg further dwells upon the principles of criminal law, he comes to the conclusion of existing two groups of basic principles of Soviet criminal law. The first group encompasses the principles which are common to all branches of Soviet law, including the criminal law, so he refers to them as general law principles, and the second includes those specific exclusively to the criminal law. However, the author does not in any way attempt to find out the specifics of the first group principles of criminal law, nor does he attempt to characterize the specific features of those belonging to the second group.

We also cannot agree on the list of individual principles, as we do not view them as such. In particular, the scholar assigns to the basic principles of criminal law such principles as the crime prevention, comprehensive protection of the individual, public participation in the fight against crime, etc. We are convinced that the crime prevention could not refer exclusively to the criminal law, because during the Soviet time it was fulfilled mostly through the economic, educational, pedagogical and ideological measures. We believe that the crime prevention is one of the main tasks of criminal law rather than the principle thereof.

We also consider it a mistake to refer the comprehensive protection of the individual to the basic principles of Soviet criminal law, as $\mathrm{H}$. Wittenberg emphasized. The mistake may be explained in the same way, in our view. Except that other branches of law also apply the principle of protection of the individual, the latter is one of the most important tasks of the criminal law, either.

Finally, we definitely cannot agree that the public participation in fight against crime may be referred to the principles of criminal law. This is a broad concept of public life and of many government institutions, of course, may be referred not only to the criminal law. "The criminal law," as the Soviet researcher Yu. Demydov noted "only governs the application of social pressure and disciplinary measures to the perpetrators of a crime" [14, p. 20].

The aforementioned author describes the basic principles of Soviet law as the most general, steady and significant correlations of crimes to the criminal responsibility and measures of social pressure applied in place of criminal responsibility and governed by the criminal legislation in order to protect the socialist order from criminal encroachments [14, p. 22].

For the same reasons, we believe that the specific principles of criminal law cannot include "the principle of responsibility for a specific socially dangerous act" and "the dialectical unity of the substantive and formal in establishing limits for justifiable defense, and in creating key institutions of criminal justice". Another Soviet scholar A. Sakharov also supported the introduction of such principles of criminal law, at his time [15, p. 59]. However, we consider that the former principle is covered by the other principle of "discrimination in sentencing". The second, as rightly emphasized by the criminal 
law experts, is a general-methodological approach to the learning not only legal but also other social life aspects [16, p. 10].

Such Soviet scientists as $S$. Kelin and V. Kudryavtsev also contributed to the elaboration of the principles of criminal law. In one of their joint works they expressed a well-grounded opinion that there are no exclusive branch principles of law, including the criminal law ones. According to them, the general principles of law are applicable to all or almost all branches of law. They are distinguishing for each branch of law depending on the subject and method of legal regulation, as well as the specificity of tasks and functions inherent in a particular branch of law [17, p. 62].

The authors consider that the above definitions and features of the principles of Soviet criminal law are also the distinguishing features thereof. It should be noted that most Soviet researchers usually mention only the distinguishing features of the principles common to a certain branch of law rather than giving the general definition of the term itself. Such ambiguity in key concepts makes it impossible to understand what the special principles of criminal law are and what their concept is.

By exploring the principles of Soviet criminal law, we found out that there was no consensus among scholars with regard to the steadiness (stability) or vice versa - the dynamics of the principles of law in general and of the criminal law in particular. A great part of the scholars argued for the principles steadiness and constancy $(\mathrm{H}$. Wittenberg, H. Krieger) [18, p. 102-107]. In our view, such a statement is highly questionable, as it ignores the interdependence of the principles on ideology, morality, socio-economicexistence of society, national cultures, which are also changing dynamically. A retrospective view gives us the opportunity to claim that even within the chronological framework of our study, the principles and tasks of criminal law have undergone a significant transformation. During this period, such principles as internationalism, public participation in the fight against crime, etc. were excluded from the system of criminal law. These facts give us the opportunity to observe their transformation in the doctrine of Soviet, Ukrainian, and Chinese law.

The same grounds show the unsubstantiated existence of the "universal" principles of Soviet law in general and of criminal law in particular. We consider a well grounded position of the contemporary scholar V. Stepashyn, who argues that the term "universality" can be applied only to versatile, optional features of the principles of law, "since their concept, even with the constancy of names, can change dramatically over a small period of time (e.g. the principles of democracy, personal responsibility, and humanism)" [19, p. 194].

What specific principles of Soviet criminal law were outlined as being inherent in the socialist system of law of the Soviet Union in general and Soviet Ukraine in particular? The Soviet theorist of criminal law Yu. Demydov believes that the basic principles of criminal law include the principle of liability for guilt, the principle of personal criminal responsibility, the principle of compliance of criminal liability with the gravity of offence and the criminal himself, the individualization of criminal responsibility, the principle of sentencing only when the correction and re-education may not be achieved by other means [14, p. 22]. All of the above concepts refer to the basic principles of criminal law. Instead, a logical question is, if we have basic principles, there should be additional or complementary ones as well. Unfortunately, the author did not answer this question in his work.

The academic circle also failed to receive the answer from the joint work "The Course in Soviet Criminal Law," which came out as a textbook in 1968. The section on subjects, methods and scope of the Soviet criminal law suggests its general principles as follows: socialist humanism and democracy, socialist legitimacy, Soviet patriotism and proletarian internationalism. In addition, it considers such principles of Soviet Union criminal law as: the consistent implementation of Lenin's provisions on the unity of socialist legitimacy in the country; enhancing crime prevention by engaging the wide range of Soviet public to the fight against crime; legal guarantees of law enforcement in the administration of justice; further development of socialist humanism (narrowing and alleviating criminal responsibility for minor crimes, etc.); impact on the conditions which facilitated the commission of crimes [20, p. 9-18, 130].

At the beginning of reformation of the Soviet criminal law in the late 1980s, S. Kelina and V. Kudryavtsev offered a system of "internally agreed, interrelated" principles, which included the following principles of criminal law: legality, equality, personal responsibility, guilty liability, inevitability, justice, humanism and democracy $[17$, p. 64]. This list of principles and features were considered to be the most appropriate and were widely used in the scientific doctrine of the Soviet criminal law and legislation, including in individual Soviet republics.

Our task is to study the level of implementation of the principles of Soviet law in the legislation of the USSR and the Ukrainian SSR. To this end, we investigated the criminal legislation of both the USSR and Soviet Ukraine to come to the conclusion that only a small part of the principles of Soviet criminal law formed the basis for the criminal legislation and vice versa. Thus, the principle of liability for guilt is provided by Art. 3 of The Fundamentals of the Criminal Law of the USSR and the Union Republics of December 25, 1958, which was fully reproduced in an identical article of the Criminal Code of the USSR of December 28, 1960. Both documents reveal the concept of this principle, which stated that criminal liability and punishment 
might be imposed only upon a person guilty of a crime, that is, on the person who intentionally or negligently committed a socially dangerous act as provided for in criminal law.

The principle of socialist legitimacy was formalized in Art. 7 of the Fundamentals and Criminal Code of the USSR, where a crime was recognized as a socially dangerous act (action or omission) prescribed by criminal law.

The principle of equality of citizens before the law is provided for in the Fundamentals of the Judiciary of the USSR, Art. 8 of the Fundamentals of the Criminal Proceedings and Art. 16 of the Code of Criminal Procedure of the USSR. All the above legal acts state that criminal justice is carried out on the basis of equality of citizens before the law and the court, regardless of origin, social and property status, race and nationality, gender, education, language, religion belief, occupation, place of residence or other conditions.
The principle of justice found its place in Art. 2 of the Fundamentals of the Criminal Proceedings of the USSR and the Union Republics as one of the tasks of the Soviet judiciary. The Fundamentals provides for that a person who committed a crime shall be submitted to a just punishment.

Conclusions. Thus, the Soviet legal and criminal theory had made attempts to provide the definition for "the special principles of criminal law" and to determine their scope and concept. However, there was no agreed approach of scholars on this matter. Some of Soviet theorists assigned such ideological paradigms as "socialist legitimacy," "Soviet patriotism" et al to the principles of criminal law. A number of the principles of criminal law which were outlined by Soviet theorists and existing in theoretical and criminal doctrine had never found their reflection in the criminal legislation of the Soviet Union in general and Soviet Ukraine in particular.

\section{References:}

1. Грищук О. Принципи права: філософсько-правовий вимір. Вісник Львівського університету. Серія «Юридична». 2015. Вип. 61. С. 16-23.

2. Козюбра М. Принципи права: методологічні підходи до розуміння природи та класифікації в умовах сучасних глобалізацій них трансформацій. Право Украӥни. 2017. № 11. С. 142-164.

3. Рабінович П.М. Основи загальної теорії права і держави : навчальний посібник. 9-те вид., зі змін. Львів : Край, 192 с.

4. Скакун О.Ф. Теорія права і держави : підручник. 3-є вид. Київ : Алерга, 2012. 524 с.

5. Погребняк С.П. Основоположні принципи права (змістовна характеристика). Харків : Право, 2008. 240 с.

6. Зайчук О.В. Принципи права в контексті розвитку загальної теорії права та держави.

7. Луць Л.А. Загальна теорія держави і права : навчально-методичний посібник (за кредитно-модульною системою). Київ : Атіка, 2007. 412 с.

8. Колодій А.М. Принципи права: генеза, поняття, класифікація та реалізація. Альманах права. 2012. Вип. 3. С. 42-46.

9. Загальна теорія права : підручник / за заг. ред. М.І. Козюбри. Київ : Ваіте, 2015. 392 с.

10. Фулей Т.І. Сучасні загальнолюдські принципи права та проблеми їхнього впровадження в Україні : дис. ... канд. юрид. наук : 12.00.01 «Теорія та історія держави і права; історія політ. і прав. вчень». Львів, 2003. 253 с.

11. Якуб М.Л. О понятии принципа уголовного права и уголовного процесса. Правоведение. 1976. № 1. C. 56-64.

12. Загородников Н.И. Принципы советского социалистического уголовного права. Советское государство и право. 1966. № 5. С. 71-74.

13. Виттенберг Г.Б. Развитие основных принципов советского уголовного права в новом Уголовном кодексе РСФСР. Правоведение. 1962. № 4. С. 88-90.

14. Демидов Ю.А. Основные принципы советского уголовного права. Вопросы борьбы с преступностью. 1969. № 9. C. 19-29.

15. Сахаров А.Б. О принципах социалистического уголовного права. Правоведение. 1969. № 4. С. 54-56.

16. Фефелов П.А. Понятие и система принципов советского уголовного права. Свердловск : Среднеуральское книжное издательство, 1970. 144 с.

17. Келина С.Г., Кудрявцев В.Н. Принципы советского уголовного права. Москва : Наука, 1988. 176 с.

18. Кригер Г.А. Место принципов уголовного права в системе принципов права. Советское государство и право. 1981. № 2. С. 102-107.

19. Степашин В.М. Понятие принципа уголовного права. Вестник Омского университета. Серия «Право». 2017. № 1. C. 192-196. $511 \mathrm{c}$

20. Курс советского уголовного права : в 6 т. / ред. кол. А.А. Пионтковский и др. Ленинград : ЛГУ, 1968. Т. 1. 